\title{
PROFIL TINGKAT KEBUGARAN ANAK USIA 5-14 TAHUN KOTA ADMINISTRATIF JAKARTA TIMUR
}

\author{
Fajar Vidya Hartono \\ e-mail: fajarvidya@yahoo.co.id \\ Dosen FIK Universitas Negeri Jakarta
}

\begin{abstract}
Abstrak: Profil Tingkat Kebugaran Anak Usia 5-14 Tahun Kota Administratif Jakarta Timur. Penelitian ini bertujuan untuk mengetahui sejauh mana tingkat kebugaran anak-anak usia rentang 5 sampai dengan 14 tahun di kota Administratif Jakarta Timur. Penelitian ini menggunakan teknik tes dan nontes dengan metode survey. Pengumpulan sampel dengan menggunakan teknik proportionate stratified random sampling, sampel yang diambil sebanyak 121 anak. Sampel di tes dengan menggunakan tes kebugaran jasmani MFT (Multistage Fitness Test) tes kebugaran MFT ini lebih dikenal dengan blip tes, bip tes, pacer tes, atau 20 meter lari bolak balik, MFT merupakan serangkaian tahapan yang memiliki level berbeda terkadang digunakan oleh pelatih olahraga dan trainer untuk mengetahui tingkat penyerapan oksigen maksimal atau VO2max. pacer tes merupakan tes daya tahan kardiovaskular. Tes ini sangat berguna untuk olahraga dengan tingkat aerobik yang progresif seperti rugby, sepak bola, Australia Footbal, Gaelik Footbal, Hurling, Hockey, Netball, Bola tangan, tennis, swuash, dan tes kesegaran jasmani di sekolah dan kuliah atau kampus atau olahraga lainnya, digunakan oleh beberapa tim olahraga internasional sebagai tes kebugaran kardiovaskular yang akurat, salah satu komponen yang penting dari kesegaran jasmani. Data yang telah dikumpulkan diolah dan dianalisis dengan menggunakan teknik statistik deskriptif. Dari pengukuran yang telah dilakukan, dapat disimpulkan bahwa secara umum tingkat kebugaran anak usia 5-14 tahun memiliki nilai dalam kategori tinggi, kecamatan dengan tingkat kebugaran tertinggi terdapat di Kecamatan Makasar dengan rasio 31.98 dan yang terendah berada di Kecamatan Duren Sawit dengan rasio 22.42. Hasil penelitian diketahui bahwa kebugaran jasmani berkaitan dengan performa dalam melakukan aktifitas sehari-hari secara berkesinambungan, sehingga menjadikan performa yang lebih baik dan akan menghasilkan tingkat kebugaran jasmani yang lebih baik. Derajat kebugaran anak-anak mempengaruhi prestasi belajar mereka dan aktivitas bermain yang sifatnya membutuhkan energi karena masa perkembangan anak usia 5-14 tahun merupakan fase pertumbuhan motorik yang apabila diarahkan dengan lebih baik akan menjadi potensi yang luar biasa di masa datang.
\end{abstract}

Kata kunci: tingkat kebugaran, anak usia 5-14, kota Administratif Jakarta Timur.

\section{CHILDREN AGED 5 - 14 YEARS FITNESS LEVEL PROFILE IN JAKARTA TIMUR}

\begin{abstract}
Children aged 5 - 14 years Fitness level profile in Jakarta Timur, this research aims to determine the extent to which fitness level children age range 5 till 14 years old in Jakarta Timur. This research using a test and non test techniques with the survey method. A collection for the sample using a proportionate stratified random sampling techniques. As many as 121 children as sample. Tested using a MFT (Multistage Fitness Test) The multi-stage fitness test, also known as the bleep test, beep test, pacer test, Leger-test or 20-m shuttle run test, is a series of stages that have different tasks sometimes used by sports coaches and trainers to estimate an athlete's VO2 max(maximum oxygen uptake). The pacer test is "progressive aerobic cardiovascular endurance test". The test is especially useful for players of sports such as rugby, football, Australian rules football, Gaelic football, hurling, hockey, netball, handball,tennis, squash, and fitness testing in schools and colleges plus many other sports; employed by many international sporting teams as an accurate test of cardiovascular fitness, one of the more important components of Fitness. The existing data then processed and analyzed with a statistic deskriptif techniques. From measurements made it can be concluded that in general a children fitness level has a high point category, the district who has a high fitness level points in sub-district Makasar with ratio 31.98 points, and a lowest fitness level points located in sub-district Duren Sawit with 22.42 level points ratio. The survey result revealed is physical fitness related to a good activity perform and it will to conduce a better fitness level. Level of fitness predispose a learning achievement and all of activities who nature playing and requires a lot of energy because a children growth aged 5 - 14 years
\end{abstract}




\section{PENDAHULUAN}

Kebugaran jasmani merupakan faktor penting dan mutlak yang harus dimiliki semua orang, faktor tersebut penting guna menunjang terciptanya aktivitas fisik yang baik dan produktif. Toho Cholik Mutohir dan Ali Maksum (2007:15) menyatakan bahwa kebugaran jasmani adalah kesanggupan tubuh melakukan aktivitas tanpa mengalami kelelahan yang berarti. Orang yang bugar berarti ia tidak gampang lelah dan capek. la dapat mengerjakan pekerjaan sehari-hari secara optimal, apabila seseorang memiliki kebugaran jasmani yang rendah maka dapat mengalami penurunan ketahanan fisik dan psikis sehingga prestasi pekerjaan tidak maksimal dan belajar tidak memuaskan.

Kebugaran jasmani merupakan salah satu kunci kesehatan dan keburagan badan yang merupakan salah satu dasar aktivitas gerak. Hasnan Said (1979:1) mengemukakan bahwa fisik yang kuat dengan fungsi yang mampu diandalkan dari semua organ tubuh merupakan jaminan bagi seseorang untuk dapat mewujudkan kemampuannya melakukan aktivitas fisik tanpa timbulnya rintangan akan kehabisan atau kekurangan tenaga dan aktivitas kalau "sehat" diartikan secara ringkas dan tidak ada penyakit dan kelainan, maka "segar" mengandung arti yang lebih luas daripada itu.

Kadang-kadang pengertian jasmani disamakan dengan kebugaran motorik meskipun sebenarnya kesegaran motorik merupakan bagian dari kebugaran jasmani. Dari berbagai pendapat di atas mengenai kebugaran jasmani maka sangat jelas bahwa setiap manusia idealnya harus memiliki tingkat kebugaran jasmani yang baik guna menunjang aktivitas fisik yang dinamis dalam kehidupannya seperti bekerja, belajar, dan lain sebagainya.

Aktivitas olahraga ikut memegang peranan penting untuk meningkatkan kebugaran jasmani seseorang sehingga selalu berada dalam keadaan fit. Engkos Kosasih (1995:10) mengemukakan bahwa seseorang dikatakan dalam keadaan fit apabila memiliki komponen-komponen kebugaran jasmani dan dapat melakukan pekerjaan secara efisien tanpa menimbulkan kelelahan yang berarti. Terdapat tiga aspek kebugaran jasmani dalam artian sempit yaitu; pertama, kesegaran statis atau medis yaitu keadaan kemantapan organ tubuh seperti jantung dan paru- paru; kedua, kesegaran dinamis atau fungsional pada tubuh manusia sehubungan dengan jarak kerja optimal; ketiga, kesegaran keterampilan gerak atau keterampilan motorik yaitu tingkat kemantapan koordinasi dan kekuatan dalam penampilan kegiatan.

Sedangkan kebugaran jasmani dalam arti luas adalam kemampuan berbuat dari fisik, mental dan spiritual dengan sebaik-baiknya untuk melaksanakan tugas dan kewajiban pribadinya. Aip Syarifudin (1998:24) mengemukakan kebugaran jasmani adalah kemampuan yang dimiliki oleh seseorang untuk melakukan suatu pekerjaan yang cukup berat dan cukup lama tanpa mengalami kelelahan yang berarti. Ini berarti bahwa kemampuan kebugaran jasmani seseorang harus dilatih sejak dini karena, seseorang yang melatih atau memiliki tingkat kebugaran jasmani yang baik sejak dini akan memiliki tenaga cadangan untuk menghadapi suatu pekerjaan yang mendesak, meskipun baru melakukan suatu pekerjaan yang berat dan cukup lama.

Salah satu upaya yang paling penting baik untuk membina dan meningkatkan kebugaran jasmani (physical fitness) adalah dengan cara latihan kekuatan, daya tahan, dan beberapa unsur lain yang menyangkut aktivitas gerak manusia. Latihan tersebut sejatinya dapat dilakukan sejak anakanak. Perkembangan anak usia 5-14 tahun sangat cepat, pada masa ini pertumbuhan bagian-bagian tubuh mengalami perubahan dalam peningkatan pertumbuhan otot. Pada masa ini tampak pertumbuhan anak yang mengarah pada tipe bentuk tubuh, terdapat tiga tipe tubuh kearah mana anak akan tumbuh yaitu, mesomorph, endomorph, dan ectomorph. Perkembangan kemampuan fisik terjadi sejalan dengan pertumbuhan yang baik. Semakin baik pertumbuhan fisiknya semakin memungkinkan seseorang meningkatkan kemampuan fisiknya.

Manfaat kebugaran jasmani bagi tubuh salah satunya dapat mencegah berbagai penyakit seperti jantung, pembuluh dara, dan paru-paru sehingga dapat meningkatkan kualitas hidup secara keseluruhan. Pembentukan dan pencegahan tumbuhnya berbagai penyakit tersebut sejatinya dilakukan sejak dini, dengan jasmani yang bugar hidup menjadi semangat dan menyenangkan. Kebugaran jasmani tidak hanya menggambarkan kesehatan. Tetapi lebih merupakan 
cara mengukur individu melakukan kegiatan sehari-hari yang sifatnya aktivitas berat dan berkesinambungan yang dilakukan dengan menggunakan tenaga yang stabil.

Ditambahkan oleh Harsono (1988:176) yang mengatakan bahwa kekuatan adalah kemampuan otot untuk membangkitkan tegangan atau force terhadap suatu tahanan dengan kata lain kekuatan merupakan kemampuan kontraksi otot yang mengangkat atau menahan beban, makin besar penampang otot maka akan semakin besar kekuatan yang dihasilkan. Perkembangan kekuatan pada usia 5-14 tahun mengalami percepatan perkembangan yang signifikan untuk laki laki terjadi dalam rentang usia setelah 11-12 tahun dan untuk wanita pada usia setelah 9-10 tahun.

Kelentukan merupakan kemampuan sendi untuk melakukan gerakan dalam ruang gerak sendi secara maksimal sesuai dengan kemungkinan geraknya. Perkembangan fleksibilitas terjadi juga pada anak rentang usia ini, fleksibilitas adalah keleluasaan gerak persendian. Keleluasaan ini memiliki pengaruh gerak terhadap anak dalam menguasai gerakan olahraga seperti gerakan keseimbangan.

Komposisi tubuh yang baik merupakan komposisi relatif dari lemak tubuh dan massa tubuh dimana komposisi tersebut dinyatakan dengan Indeks Massa Tubuh (IMT) yakni berat badan dalam kilogram dibagi dengan tinggi badan kuadrad dalan meter. Selain itu juga dinyatakan dalam prosentase lemak tubuh yakni perbandingan antara berat lemak tubuh dan berat badan yang diperoleh berdasarkan ketebalan lemak.

Daya tahan adalah kemampuan untuk melakukan suatu gerakan atau usaha melewati suatu periode waktu. Harsono (1988) menjelaskan bahwa daya tahan merupakan keadaan atau kondisi tubuh yang mampu bekerja untuk waktu yang lama tanpa mengalami kelelahan yang berlebihan setelah menyelesaikan aktifitas tersebut.

Kebugaran jasmani yang berhubungan dengan keterampilan diantaranya adalah kecepatan yang merupakan kemampuan berpindah secara cepat dari suatu tempat ke tempat yang lain. Seperti yang dikatakan Harsono (1988) kecepatan adalah kemampuan untuk melakukan gerakan-gerakan yang sejenis secara berturut-turut dalam waktu yang sesingkat-singkatnya, atau kemampuan untuk menempuh suatu jarak dalam waktu yang cepat.

Daya atau power merupakan gabungan antara kekuatan dan kecepatan atau pengerahan otot secara maksimum. Kelincahan atau agility adalah kemampuan bergerak dengan berubah-ubah arah secara cepat dan tepat tanpa kehilangan keseimbangan. Koordinasi menunjuk kepada terjadinya hubungan yang harmonis antara berbagai bagian yang mewujudkan suatu gerak yang lancer dan efisien sedangkan kecepatan reaksi yang berkaitan dengan waktu yang diperlukan dari saat diterimanya stimulus atau ransangan sampai awal munculnya respon atau reaksi.

Keseimbangan adalah kemampuan untuk mempertahankan posisi tubuh untuk tidak bergoyang atau roboh, baik pada posisi diam maupun pada saat melakukan gerakan. Ada dua jenis keseimbangan yaitu statis dan dinamis, keseimbangan statis adalah kemampuan mempertahankan tubuh dalam keadaan diam sedangkan dimanis adalah kemampuan mempertahankan tubuh dalam keadaan bergerak.

Kemampuan dasar seperti yang dijelaskan diatas seharusnya dimiliki oleh anak-anak agar nanti ketika dewasa memiliki bekal kebugaran jasmani guna menunjang aktivitas pekerjaan dan belajar yang baik, oleh karena itu diperlukan sebuah profil tingkat kebugaran anak usia 5-14 tahun sebagai acuan untuk mengembangkan sumber daya manusia yang produktif di masa yang akan datang.

\section{METODE PENELITIAN}

Penelitian ini menggunakan teknik tes dan nontes, teknik tes yang digunakan adalah Multistage Fitness Test (MFT) untuk menjaring data tentang tingkat kebugaran jasmani sedangkan teknik non tes dilakukan untuk menjading data partisipasi olahraga yang menunjang kebugaran jasmani tersebut. Penelitian ini dilakukan pada bulan Desember 2013. Populasi dalam penelitian ini adalah anak-anak usia 5-14 tahun di wilayah Kota Administratif Jakarta Timur. Sampel yang digunakan untuk mengukur dimensi kebugaran jasmani dengan teknik penarikan sampel
Propotionate Stratified Random Sampling. Adapun jumlah sampel yang diambil sebanyak 121 orang anak. Adapun penyebaran berdasarkan daerah kecamatan di wilayah Kota Administratif Jakarta Timur adalah sebagai berikut; Cakung: 12 anak, Cipayung: 12 anak, Ciracas: 12 anak, Duren Sawit: 12 anak, Jatinegara: 12 anak, Kramat Jati: 12 anak, Makasar: 13 anak, Matraman: 12 anak, Pasar Rebo: 12 anak, Pulo Gadung: 12 anak. Total sampel 121 orang anak.

Data dari lapangan setelah diverifikasi kemudian dipindahkan kedalam lembaran-lembaran data, 
kemudian diolah dan dianalisis dengan menggunakan teknik statistik deskriptif. Deskripsi data dari hasil penelitian yang bertujuan untuk memberikan gambaran umum mengenai variabel tingkat kebugaran jasmani anak usia 5-14 tahun di wilayah Kota Administratif Jakarta Timur.

\section{HASIL DAN PEMBAHASAN}

Untuk mengetahui tingkat kebugaran jasmani seseorang dapat dilihat dari indikator-indikator yang terjadi. Menurut Sastropanoelar (1992:7) Indikator tingkat kebugaran jasmani seseorang adalah kemampuan atau kapasitas seseorang untuk menggunakan oksigen sebanyak-banyaknya (kapasitas Aerobik Maksimal = VO2Max). salah satu cara mengukur dan menentukan kesegaran kardiovaskular adalah mengukur besarnya VO2Max.

Mahardika (2008) mengemukakan bahwa jenis tes kebugaran jasmani yang paling baik dan fisibel untuk dilaksanakan diantaranya adalah tes MFT (Multistage Fitness Test) karena pada saat melakukan pelaksanaan test, MFT tidak memerlukan lintasan lari yang terlalu panjang yaitu hanya sekitar 20 meter. Selain itu hasil tes berupa tingkat VO2Max dapat dilihat langusng pada tabel hasil MFT sehingga derajat kebugaran seseorang dapat terlihat tanpa harus melakukan perhitungan terlebih dahulu.

Hasil penelitian diketahui bahwa kebugaran jasmani berkaitan dengan performa dalam melakukan aktifitas sehari-hari secara berkesinambungan, sehingga menjadikan performa yang lebih baik dan akan menghasilkan tingkat kebugaran jasmani yang lebih baik. Rusli Lutan (2001:63) mengemukakan bahwa performa mengandung unsur-unsur koordinasi, agilitas, kecepatan gerak, power dan keseimbangan. Untuk memperoleh kebugaran jasmani yang menyeluruh, setiap komponen diatas tidak dapat diabaikan karena saling berkaitan satu sama lainnya.

Koordinasi merupakan kemampuan utnutk melakukan tugas gerak terpisah yang didukung penghindaran sehingga gerak menjadi efisien, jika seorang anak dilatih koordinasi yang baik maka akan baik pula tingkat kebugaran jasmaninya. Agilitas merupakan kemampuan untuk mengubah arah secara cermat sementara tubuh sedang bergerak dari satu tempat ke tempat yang lain secepat mungkin. Power merupakan kemampuan untuk mengerahkan usaha semaksimal mungkin atau sering disebut dengan istilah daya ledak, makin besar daya ledaknya semakin baik pula tingkat kebugaran jasmaninya. Keseimbangan memerlukan kemampuan yang beriringan dengan daya gravitasi, keseimbangan yang baik didukung oleh kemampuan power yang baik maka semakin baik pula kebugaran jasmaninya.
Pengukuran hasil tingkat VO2Max dilakukan dengan menggunakan MFT dengan panjang lintasan keseluruhaan 20 meter. VO2Max merupakan nilai tertinggi dimana seseorang dapat mengkonsumsi oksigen selama latihan, serta merupakan refleksi dari unsur kardiorespirasi dan hematologik dari pengantaran oksigen dan mekanisme oksidatif otot. Orang dengan tingkat kebugaran yangbaik memiliki nilai VO2Max lebih tinggi dan dapat melakukan aktivitas lebih kuat dibanding mereka yang tidak dalam kondisi baik. Tenaga aerobik maksimal, sering kali disebut penggunaan oksigen maksimal,adalah tempo tercepat dimana seseorang dapat menggunakan oksigen selama olahraga yang dalam litelatur fisiologis tenaga aerobik maksimal disingkat sebagai VO2Max (Pate, 1993:255) menjelaskan bahwa VO2Max adalah kecepatan terbesar pemakaian oksigen dan merupakan ukuran mutlak kecepatan terbesar dimana seseorang dapat menyediakan energi ATP dengan metabolisme aerobik.

VO2Max atau volume oksigen maksimal, merupakan suatu ukuran kapasitas setiap individu dalam menghasilkan energi yang diperlukan saat aktifitas daya tahan. VO2Max adalah salah satu faktor yang paling utama untuk menentukan kemampuan individu yang beraktivitas lebih lama dan panjang.

Kemampuan seseorang dalam menggunakan oksigen selama kegiatan maksimal disebut dengan daya aerobic maksimal, kapasitas aerobic maksimal biasanya dinyatakan dengan maksimal uptake dan merupakan salah satu faktor penting untuk menunjang prestasi belajar dan ketahanan fisik anak-anak.

Tingkat VO2Max setiap anak berbeda-beda. Beberapa ahli menyebutkan ada beberapa faktor yang menentukan tingkat VO2Max seseorang. Engkos Kosasih (1985) mengemukakan ada empat faktor yaitu ; 1) faktor genetik atau keturunan; 2) faktor latihan yang dijalankan; 3) faktor teknik yang dipakai dalam latihan; 4) faktor kemajuan teknik atau perlengkapan yang menunjang.

Sedangkan Pate (1993) menjelaskan faktorfaktor yang menentukan nilai VO2Max diantaranya adalah fungsi paru-paru dan kardiovaskular yang pada saat melakukan aktivitas fisik dengan intens terjadi penigkatan kebutuhan oksigen oleh otot yang 
sedang bekerja. Kebutuhan oksigen ini didapat dari ventilasi dan pertukaran oksigen dalam alveoli paru dan cara difusi. Oksigen yang terdifusi masuk dalam kapiler paru untuk selanjutnya diedarkan melalui pembuluh darah ke seluruh tubuh. Untuk dapat memasok kebutuhan oksigen yang kuat, dibutuhkan paru-paru yang berfungsi dengan baik termasuk juga kapiler dan pembuluh pulmonalnya. Pada seseorang yang terlatih dengan baik konsumsi oksigen dan ventilasi paru total meningkat sekitar 20 kali pada saat melakukan aktivitas dengan intensitas maksimal. Dalam fungsi paru, dikenal dengan istilah perbedaan oksigen arterivena (A-V02 diff). selama aktivitas fisik yang intens A-V 02 akan meningkat karena oksigen darah lebih banyak dilepas ke otot yang sedang bekerja sehingga oksigen darah vena berkurang. Hal ini menyebabkan pengiriman oksigen ke jaringan naik hingga tiga kali lipat daripada kondisi biasa. Peningkatan cardiac output dan pertukaran udara sebagai respon terhadap olahraga berat.

Fungsi kardiovaskuler yang paling utama terhadap aktivitas fisik adalah peningkatan cardiac output. Peningkatan ini disebabkan oleh peningkatan isi sekuncup jantung maupun heart rate yang dapat mencapai sekitar 95\% dari tingkat maksimalnya. Karena pemakaian oksigen oleh tubuh tidak dapat lebih dari kecepatan system kardiovaskuler menghantarkan oksigen ke jaringan, maka dapat dikatakan bahwa system kardiovaskular dapat membatasi nilai VO2Max.

Karena dalam darah oksigen berikatan dengan hemoglobin, maka kadar oksigen dalam darah juga ditentukan oleh kadar hemoglobin yang tersedia. Jika kadar hemoglobin berada di bawah normal, misalnya pada anemia maka jumlah oksigen dalam darah juga lebih rendah. Sebaliknya bila kadar hemoglobin lebih tinggi dari normal, seperti pada keadaan polisitemia, maka kadar oksigen dalam darah akan meningkat. Hal ini juga bisa terjadi sebagai respon adaptasi pada orang-orang yang hidup di tempat tinggi. Kadar hemoglobin rupanya juga dipengaruhi oleh hormon androgen melalui peningkatan pembentuka sel darah merah. Laki-laki memiliki kadar hemoglobin sekitar 1-2 gr per $100 \mathrm{ml}$ lebih tinggi dibanding wanita.

Jaringan lemak menambah berat badan, tapi tidak mendukung kemampuan untuk secara langsung menggunakan oksigen selama olahraga berat. Maka jika VO2Max dinyatakan relative terhadap berat badan, berat lemak cenderung menaikkan angka penyebut tanpa menimbulkan akibat pada pembilang VO2Max : VO2 $(\mathrm{mk} / \mathrm{kg} / \mathrm{menit})=$ VO2 (L02) x 1000 : Berat badan (kg) jadi kegemukan cenderung mengurangi VO2Max.

Penelitian cross-sectional dan longitudinal nilai VO2Max pada anak usia 5-14 tahun yang tidak dilatih menunjukkan kenaikan progresif dan linier dari puncak kemampuan aerobik, sehubungan dengan umur kronologis pada anak perempuan dan laki-laki. VO2Max anak laki-laki menjadi lebih tinggi mulai umur 10 tahun walau ada yang berpendapat latihan ketahanan tidak terpengaruh pada kemampuan aerobic sebelum usia 11 tahun. Puncak nilai VO2Max dicapai pada usia 18 tahun pada kedua jenis kelamin.

Secara umum kemampuan aerobic turun perlahan setelah usia 25 tahun. Beberapa penelitian menemukan bahwa penurunan rata-rata VO2Max pertahun adalah $0.46 \mathrm{ml} / \mathrm{kg} /$ menit untuk pria $(1.2 \%)$ dan $0.54 \mathrm{ml} / \mathrm{kg} / \mathrm{menit}$ untuk wanita (1.7\%). Penurunan ini terjadi karena beberapa hal termasuk reduksi denyut jantung maksimal dan isi sekuncup jantung maksimal.

Kemampuan aerobic wanita sekitar $20 \%$ lebih rendah dari pria pada usia yang sama. Hal ini dikarenakan perbedaan hormonal yang menyebabkan wanita memiliki konsentrasi hemoglobin lebih rendah dan lemak tubuh lebih besar. Wanita juga memiliki massa otot lebih kecil daripada pria. Mulai umur 10 tahun, VO2Max anak laki-laki menjadi lebih tinggi $12 \%$ dari anak perempuan. Pada umur 12 tahun perbedaannya menjadi $20 \%$ dan pada umur 16 tahun VO2Max anak laki-laki 37\% lebih tinggi dibanding anak-anak perempuan. Sehubungan dengan jenis kelamin wanita. Lebrun melakukan penelitian pada tahun 1995 pada 16 wanita yang mendapat latihan fisik sedang, melakukan pengukuran serum estradiol dan progesterone untuk memantau fase-fase menstruasi. Dari penelitian tersebut didapatkan bahwa VO2Max absolute meningkat selama fase folikuler dibanding dengan fase luteal. Pada fase luteal menstruasi, kadar progesterone meningkat. Padahal progesterone memiliki efek termogenik, yaitu dapat meningkatkan suhu basal tubuh. Efek termogenik dari progesterone ini rupanya meningkatkan BMR sehingga akan berpengaruh pada kerja kardiovaskuler dan akhirnya berpengaruh pula pada nilai VO2Max. sehingga secara tidak langsung perubahan suhu akan berpengaruh pada nilai VO2Max. 
Tabel 1. Indeks Rasio Angka Kebugaran

\begin{tabular}{|c|l|c|c|c|c|}
\hline No & Kecamatan & $\begin{array}{c}\text { Nilai } \\
\text { Aktual } \\
\text { Kebuga- } \\
\text { ran }\end{array}$ & $\begin{array}{c}\text { Nilai } \\
\text { Maksimal }\end{array}$ & $\begin{array}{c}\text { Nilai } \\
\text { Minimal }\end{array}$ & Indeks \\
\hline 1 & Cakung & 26,43 & 40,5 & 20,1 & 0,3103 \\
\hline 2 & Cipayung & 27,58 & 40,5 & 20,1 & 0,3667 \\
\hline 3 & Ciracas & 29,22 & 40,5 & 20,1 & 0,4471 \\
\hline 4 & Duren Sawit & 22,42 & 40,5 & 20,1 & 0,1137 \\
\hline 5 & Jatinegara & 23,93 & 40,5 & 20,1 & 0,1877 \\
\hline 6 & Kramat Jati & 23,29 & 40,5 & 20,1 & 0,1564 \\
\hline 7 & Makasar & 31,98 & 40,5 & 20,1 & 0,5824 \\
\hline 8 & Matraman & 24,72 & 40,5 & 20,1 & 0,2265 \\
\hline 9 & Pasar Rebo & 26,83 & 40,5 & 20,1 & 0,3299 \\
\hline 10 & Pulo Gadung & 29,47 & 40,5 & 20,1 & 0,4593 \\
\hline
\end{tabular}

\section{PENUTUP}

Secara keseluruhan dilihat dari pengukuran indeks yang telah dilakukan dapat disimpulkan bahwa secara umum anak-anak rentang usia 5-14 tahun di Wilayah Kota Administrasi Jakarta Timur masuk dalam golongan rendah, berdasarkan data yang terhimpun dari 9 kecamatan di wilayah tersebut.

Kecamatan Makasar memiliki nilai aktual kebugaran yang tinggi yaitu 31.98 dengan indeks rasio angka kebugaran 0.5824 . Sedangkan wilayah kecamatan dengan nilai aktual terendah terdapat di wilayah Kecamatan Duren Sawit dengan nilai 22.42 dan indeks sebesar 0.1137 .

Oleh karena itu, peningkatan kebugaran jasmani perlu diperhatikan sejak dini agar ketika dewasa nanti tingkat kebugaran akan baik dan berpengaruh pada prestasi belajar dan aktivitas bermain sehingga tidak mudah sakit.

\section{DAFTAR PUSTAKA}

Harsono. (1988). Coaching dan aspek-aspek psikologis dalam coaching. Dirjen Dikti.

Kosasih, E. (1985). Olahraga: Teknik \& program latihan. Jakarta: Akademika Presindo

Kosasih, K. (1995). Olahraga teknik dan latihan. Jakarta: CV. Kademik Prasindo.

Lutan, R. (2001). Mengajar pendidikan jasmani. Jakarta: Departemen Pendidikan Nasional Direktorat Jendral Pendidikan Dasar dan Menengah Bekerjama dengan Direktorat Jenderal Olahraga.

Mahardika, I.M.S. (2008). Pengantar evaluasi pengajaran. Surabaya: ISORI Jawa Timur.

Mutohir, T.C. \& Ali Maksum. (2007). Sport development index: Alternatif baru mengukur kemajuan pembangunan bidang keolahragaan. Jakarta: Bessindo Primalaras.

Pate, R.R., dkk. (1993). Dasar-dasar ilmiah kepelatihan (terjemahan Kasiyo Dwijowinoto). Semarang: IKIP Semarang Press.

Said, H. (1979). Kebugaran jasmani dalam pembangunan bangsa Indonesia. Jakarta: Departemen Pendidikan dan Kebudayaan.

Sastropanoelar, S. (1992). Pendidikan kesegaran jasmani. Jakarta: Departemen Pendidikan Nasional.

Syarifuddin, A. (1998). Pendidikan jasmani dan kesehatan 3. Jakarta: PT. Grasindo. 